\title{
Funkcje literatury kaszubskiej, jej potencjał edukacyjny i wykorzystanie mediów elektronicznych do jej propagowania
}

Współcześni badacze definiują literaturę kaszubską poprzez kryterium języka (Kalinowski 2014a). Pierwsze próby piśmiennictwa Kaszubów datuje się na drugą połowę XVI wieku ${ }^{1}$ Alfabet, ortografię i językowe normy gramatyczne stworzył dla kaszubszczyzny Florian Stanisław Ceynowa w latach czterdziestych XIX stulecia. Od 170 lat literatura kaszubska to narzędzie świadomie i celowo wykorzystywane w procesie porozumiewania się (Treder 2002: 102). Podstawową funkcją kaszubskojęzycznej literatury od samych jej początków aż po dzień dzisiejszy wydaje się być zachowanie własnego „ja” Kaszubów, którzy - dzięki więzi wywodzącej się z dziedzictwa kulturowego - są odrębną wspólnotą etniczną (Drzeżdżon 2007). To, co pochodzi z pradawnej spuścizny, a przetrwało w samym języku, obyczajach, wierzeniach, symbolach, zostało odbite w twórczości rodzimych pisarzy.

\section{Funkcja tożsamościowa i mitotwórcza}

Literatura kaszubska ma wywoływać radość, smutek, strach i pożądanie, co umiejscawia ją w sąsiedztwie innych tradycji literackich. Ma bawić i uczyć, a nade wszystko pomagać zrozumieć świat. Jest to w znacznym stopniu literatura tożsamościowa, odnosząca się do samoświadomości jej odbiorców. Kaszubska poezja, proza czy dramat od zarania dziejów wprowadzają w system wartości przekazywany z pokolenia na pokolenie.

Działo się tak i dzieje w obliczu zewnętrznych i wewnętrznych zagrożeń własnej tożsamości. Te pierwsze dotyczą przede wszystkim zmiany tradycyjnych związków człowieka z jego miejscem na ziemi - zamieszkiwanym terytorium (Żelazny 2006). Zagrożenia wewnętrzne zaś wynikają z jednostkowych wyborów determinowanych własnymi potrzebami (Żelazny 2006). Głównym niebezpieczeństwem dla takich mniejszości jak Kaszubi jest proces konwersji

${ }^{1}$ Za najstarszy zabytek piśmiennictwa kaszubskiego uważa się Duchowne piesnie D. Marcina Luthera ̈̈ ÿnßich naboznich męzow Zniemieckiego w Slawięsky ięzik wilozone Przes Szymana Krofea, sluge slowa Bozego W Bytowie, tłoczone w 1586 roku w Gdańsku. 
określanej jako zjawisko mniej lub bardziej świadomej zmiany dotychczasowej identyfikacji lub niewymuszone wynaradawianie się członków grup mniejszościowych.

Literacka narracja tożsamościowa Kaszubów jest oparta na historii, kulturze, obyczaju, które wiążą się z tradycją kaszubską. Istotne jest w niej myślenie symboliczne i magiczne, typowe dla kultur pierwotnych (Kulik-Kalinowska 2014). Z pokaźnego kanonu dzieł autorów kaszubskich wystarczy sięgnąc chociażby po wydaną w 1850 roku Rozmòwã Pòlôchã z Kaszëbą czy Rozmòwã Kaszëbë z Pòlôchã z 1868 roku - oba utwory napisane przez Ceynowę. Pierwszy można określić jako „podaniowo-katechizmowy” dialog "mający propagować podstawową wiedzę o Kaszubach między Słowianami" (Treder 2007: 21). Drugi zaś jest włączeniem się Kaszubów „do głównego nurtu XIX-wiecznej literatury zaangażowanej społecznie”, w której autor „ostro krytykuje nierówność stanów, szczególnie szlachtę i duchowieństwo" (Treder 2007: 44).

Funkcja tożsamościowa cechuje również poemat Hieronima Jarosza Derdowskiego Ò panu Czorlińsczim, co do Pùcka pò sécë jachôł z 1880 roku, twórczość Młodokaszubów z Janem Karnowskim, Leonem Heyke i Aleksandrem Majkowskim na czele oraz literackie dokonania Zrzeszińców - grupy poetycko-ideowej działającej w okresie międzywojennym, do której należeli między innymi: Aleksander Labuda, Jan Trepczyk czy Jan Rompski.

Do lektur obowiązkowych, powstałych w tamtych okresach, zaliczyć należy powieść Żëcé i przigodë Remusa Aleksandra Majkowskiego z 1938 roku (Majkowski 1938) i dramat Jana Rompskiego Wzénik Arkónë ukończony w roku 1939 (Rompski 2009). O pierwszym z tych utworów Daniel Kalinowski pisze, że „w swej wielowątkowości i prezentowanym systemie wartości wyrasta z kaszubskiej tradycji ludowej", ale "drugą pod względem znaczeniowym przestrzenią interpretacyjną" powieści Majkowskiego „są elementy światopoglądu romantycznego", co jest przede wszystkim wyczuwalne „w aurze kreacji literackiej” głównego bohatera powieści, który chce porwać Kaszubów do walki o własną tożsamość (Kuik-Kalinowska, Kalinowski 2009).

Podobnie rozumiał swoją twórczość Jan Rompski, który czuł powinność wskrzeszania iskry rozpalającej rodaków - tkwiących $\mathrm{w}$ dziejowym niebycie i zobojętniałych na wartości płynące z własnej kultury - do czynu. Siłą ocalającą w walce o odrodzenie i trwanie kaszubskiej wspólnoty była dla autora Wzénika Arkónë idea narodowa. Sztuka Rompskiego rozgrywa się na Rugii, a konkretnie w Arkonie - pradawnym słowiańskim grodzie, co ma znaczenie symboliczne. Duch tego miejsca ma zmartwychwstać we współczesności, by Pomorzanie-Kaszubi wstąpili „Na drogã do nowi dzys Arkónë” (Kuik-Kalinowska 2009:48).

Obie przywołane pozycje są także doskonałym przykładem funkcji mitotwórczych literatury. Czytelne dla literatury kaszubskiej motywy, figury czy obrazy wykształciły się w jej obrębie przez wszystkie lata jej istnienia (Kalinowski 2014a). To one są w zasadzie źródłem jej siły i kreacji, tworzą bowiem bogatą strukturę znaczeń.

Mity i narracja tożsamościowa nie są obce również autorom okresu powojennego, a także tym tworzącym współcześnie. Wśród wielu innych są to przede wszystkim - Jan Zbrzyca, Jan Drzeżdżon, Stanisław Janke, Krystyna Muza, Ida Czaja czy Jaromira Labuda. Warto zatrzymać się nad powieścią Twôrz Smãtka 
z 1993 roku autorstwa Drzeżdżona (1993). Kluczem do jej odczytania jest moim zdaniem esej $O$ etniczności, który autor napisał na rok przed wydaniem powieści, zaledwie kilka tygodni przed swoją śmiercią (Drzeżdżon 2007). „Można powiedzieć - pisał - że wiek dwudziesty przyniósł śmierć idei narodowych, ponieważ narody zniszczył od wewnątrz imperializm. Zatem na to miejsce wejdą ze swoją mitologią związki etniczne, które najpewniej okażą się niezwykle kulturotwórcze" (Drzeżdżon 2007: 40). Z tą nadzieją, uosobioną w postaci małego chłopca, Drzeżdżon kończy swoją ostatnią powieść.

Także wydana w roku 2013 powieść Namerkôny Artura Jabłońskiego (Jablonsczi 2013) wpisuje się w literacką tradycję. Daniel Kalinowski twierdzi, że to próba ożywienia mitów dla osiągnięcia celów pozaliterackich (Kalinowski 2014b). Zaś Adela Kożyczkowska pisze o tej powieści tak:

Budowana i przebudowywana przez Amandusa [główny bohater - A.J.] własna tożsamość stanowi ciekawy efekt nierozwiązywalnego i wiecznego konfliktu między człowiekiem a kulturą. Z jednej strony kultura potrzebna jest człowiekowi do ujarzmienia i panowania nad naturą oraz wskazywania różnych zakresów i typów relacji wewnątrz wspólnoty, a z drugiej - działa na człowieka opresyjnie: próbując go unieruchomić. Ujarzmić. Upolitycznić (Kożyczkowska 2013: 202).

Współcześnie w literaturze kaszubskiej jak w lustrze odbija się samoświadomość kulturowa najmłodszego pokolenia jej twórców i odbiorców, w której zachodzą zmiany. Literatura próbuje "oswajać” zjawiska globalne wdzierające się z impetem w kaszubską przestrzeń kulturową. W poezji najwyraźniej widać to w twórczości Hanny Makurat (2010, 2011), Gracjany Potrykus (Pòtrëkùs 2012) oraz Mateusza Tytusa Meyera (2013). W prozie literackiej u Grzegorza Schramkego (2006) czy Wojciecha Myszki (Mëszk 2014). W dramacie u Romana Drzeżdżona (2009) oraz Adama Hebla². Od kilku lat można też mówić o powrocie do felietonu kaszubskiego, który rozwijał się w okresie międzywojennym (Kalinowski 2014c). Przedstawicielami tego gatunku są obecnie Roman Drzeżdżon i Tomasz Fopke (Drzeżdżon, Fopke 2010).

\section{Potencjał edukacyjny literatury kaszubskiej}

Nauczanie języka kaszubskiego w szkołach rozpoczęło się we wrześniu 1991 roku (Mistarz 2014). Pierwsze kaszubskie szkoły powstały w Głodnicy, w gminie Linia (szkoła podstawowa) i w Brusach (liceum ogólnokształcące). Podstawą prawną do ich powołania było Zarządzenie Ministra Edukacji z 1988 roku w sprawie nauki języka ojczystego dla dzieci i młodzieży narodowości niepolskiej, które w 1992 roku zostało zmienione rozporządzeniem MEN w sprawie organizacji kształcenia umożliwiającego podtrzymywanie poczucia tożsamości narodowej, etnicznej i językowej uczniów należących do mniejszości narodowych (Mistarz 2014). Według danych Systemu Informacji Oświatowej z września

${ }^{2}$ Jego sztuka Smãtkòwô spiéwa została wystawiona dwukrotnie przez Teatr Zymk: 18 marca 2011 roku w Luzinie oraz 22 czerwca 2011 roku w Gdyni. Adam Hebel jest także autorem scenariusza najnowszej adaptacji sztuki Lecha Bądkowskiego Sąd nieòstateczny wystawianej w Filharmonii Kaszubskiej w Wejherowie przez Teatr Neokaszubia. 
2014 roku języka kaszubskiego uczyło się 18000 uczniów w 393 szkołach, w tym: w 291 szkołach podstawowych 14492 uczniów, w 112 gimnazjach 2766 uczniów oraz w 27 szkołach ponadgimnazjalnych 742 uczniów (Zgłoś dziecko na język kaszubski 2015).

Należy pamiętać, że w latach siedemdziesiątych dwudziestego stulecia w wyniku represyjnych działań państwa polskiego język kaszubski nie tylko wyrugowano ze społecznej komunikacji, ale także przerwano jego przekaz pokoleniowy. Ponieważ dzieci mówiące $\mathrm{w}$ szkole po kaszubsku spotykała dyskryminacja ze strony znacznej części nauczycieli, rodzice - $w$ trosce o ich dobro - rezygnowali $\mathrm{z}$ komunikowania się $\mathrm{w}$ tym języku w kontaktach domowych. Pod koniec lat osiemdziesiątych zaledwie kilkanaście procent młodych ludzi wykazywało się znajomością kaszubszczyzny (Mistarz 2014). Dlatego tak ważna dla odrodzenia kaszubszczyzny, które nastąpiło po demokratycznych przemianach w Polsce w roku 1989, jest edukacja szkolna. Ta ma na celu scalanie lokalnej społeczności oraz wychowywanie dzieci i młodzieży w duchu kaszubskiego patriotyzmu, budzenie tożsamości etnicznej, a co za tym idzie - rozwijanie świadomości historycznej i kulturowej (Grucza 2007).

W początkowej fazie nauczania szkolnego Kaszubi nie mieli własnych podręczników i korzystali z autorskich programów nauczania. W 1990 roku staraniem Zrzeszenia Kaszubsko-Pomorskiego zostały wydane wypisy z literatury kaszubskiej autorstwa Tadeusza Lipskiego, przygotowane z myślą o nauczycielach języka polskiego (Lipski 1990). Zaproponowane w tym opracowaniu teksty literackie stanowiły przegląd dokonań kaszubskich pisarzy do roku 1989. Dwa lata po wydaniu książki Remusowi króm. Wypisy z literatury kaszubskiej dla nauczycieli języka polskiego powstał pierwszy podręcznik dla nauczycieli kaszubskiego - Kaszubski język literacki. Podręcznik dla lektoratów - opracowany przez Różę Wosiak-Śliwę i Marka Cybulskiego z Uniwersytetu Gdańskiego - który także zawierał fragmenty klasycznych tekstów z literatury kaszubskiej (Wosiak-Śliwa, Cybulski 1992). Na potrzeby nauczania w szkole w Głodnicy zatrudniona tam nauczycielka i poetka kaszubska Jaromira Labuda przetłumaczyła na język kaszubski Brzydkie kaczątko Hansa Christiana Andersena (Andersen 1996).

Brakowało jednak nowych tekstów literackich kaszubskich autorów, a w szczególności prozy literackiej. Środowiska kaszubskie zareagowały na ten brak, organizując w 1995 roku Ogólnopolski Konkurs Prozatorski im. Jana Drzeżdżona. Konkurs ten, organizowany do dzisiaj, okazał się trafioną inicjatywą. Wydawnictwo Szos, częściowo wykorzystując przesłane prace konkursowe, wydało w 1996 roku antologię współczesnej prozy kaszubskiej Dërchôj królewiónkò. Antologia dzysdniowi prozë kaszëbsczi, w której znalazły się teksty 28 autorów. Dla szesnastu spośród nich był to w zasadzie książkowy debiut (Pryczkowski 1996). Redaktor antologii Eugeniusz Pryczkowski we wstępie do niej napisał:

Książka ma wychodzić naprzeciw potrzebom regionalistów, aktorów, nauczycieli i dzieci, którzy zajmują się rozwijaniem kaszubskiego słowa poprzez recytacje, pisanie, szukanie własnych korzeni w języku ojczystym, opowiadaniach czy legendach. W szczególności zaś książka ma przyjść z pomocą animatorom Recytatorskiego Konkursu Prozy i Poezji Kaszubskiej „Rodnô Mòwa”, którego finał co roku odbywa się w Chmielnie (Pryczkowski 1996: 5-6). 
Dopiero w 2001 roku światło dzienne ujrzał pierwszy podręcznik z ćwiczeniami Kaszëbë. Zemia i lëdze. Podręcznik do języka kaszubskiego z ćwiczeniami napisany przez nauczycielkę Danutę Pioch z myślą o dzieciach z klas I-III szkoły podstawowej (Pioch 2001). Po nim zaczęło się ukazywać mnóstwo kolejnych podręczników i szkolnych wypisów z literatury - oczywiście na miarę możliwości środowisk kaszubskich i ich potencjału. Obecnie dzieci i młodzież szkolna korzysta z własnych kaszubskich podręczników na każdym etapie kształcenia - od I klasy szkoły podstawowej poprzez gimnazjum po szkoły ponadgimnazjalne ${ }^{3}$.

Osobnym niemal już zjawiskiem staje się literatura kaszubska tworzona na potrzeby szkoły, a raczej dla „odbiorcy szkolnego" (Kalinowski 2014c). Nie wystarcza lista lektur czy podręczniki będące często także czymś w rodzaju „wypisów” z literatury kaszubskiej. Teksty literackie zaczęli tworzyć sami nauczyciele. Takim przykładem jest publikacja W krôjnie Grifa. Téatrowé scenarniczi - zbiór trzydziestu kaszubskich scenariuszy teatralnych, które w zamyśle autorek mogą być wykorzystywane zarówno przez nauczycieli języka kaszubskiego, jak też przez regionalne grupy teatralne (Pryczkowska, Wejer, Formela 2012). W tym zbiorze, o czym pisał Daniel Kalinowski,

wyczuwa się troskę [...] która wspiera ucznia na dalszej drodze tożsamościowego rozwoju. Świat teatru bowiem, przez umiejętność wywoływania tak nastroju radości, sympatii i szacunku, jak atmosfery smutku, niechęci, czy dezaprobaty, wspiera tworzenie się osobistego stosunku do świata zewnętrznego. Techniki dramaturgiczne mogą również $w$ atrakcyjny sposób świadomościowe i etnograficzne świadectwa kultury duchowej (Kalinowski 2014c: 127-128).

Inną pozycją, o podobnym charakterze i przeznaczeniu, jest zbiór teatralno-lekcyjnych scenariuszy Ùsôdzczi na wdôr... (Baska-Borzyszkowska 2013). Ich autorka Felicja Baska-Borzyszkowska sięgnęła po klasyków literatury kaszubskiej, wykorzystując ich teksty do napisania własnych montaży małych form teatralnych. One także mają zachęcać młodych ludzi do innego, bardziej aktywnego udziału w świecie kaszubskiej tradycji.

Kolejnym przykładem wykorzystania literatury kaszubskiej w procesie edukacyjnym dzieci i młodzieży jest komiks. Pomysłodawcą, animatorem i gorącym orędownikiem wykorzystywania potencjału tej formy przekazu literackiego jest Piotr Dziekanowski, wydawca i dziennikarz z Bytowa, dzięki któremu miasto to wyrasta na kaszubską stolicę komiksu. W ostatnich latach ukazały się trzy publikacje: w 2009 roku historyczny Szczeniã Swiãców (Kucharski, Natrzecy 2009), w 2012 roku fotokomiks Arbata (Natrzecy, Rolbiecki 2012), a w 2015 roku Akademiô błotowëch żółwiów (Kucharski, Nowotnik 2015) - historia przygód dwóch małych żółwi, które udowadniają moc przyjaźni.

\footnotetext{
${ }^{3} \mathrm{Na}$ poziomie szkoły podstawowej są to: D. Pioch, Kaszëbë. Zemia i lëdze. Podręcznik do języka kaszubskiego z ćwiczeniami; D. Pioch, Żëcé codniowé na Kaszëbach; D. Pioch, Najô domôcëzna; D. Pioch, Z kaszëbsczim w swiat; T. Czerwińska, A. Pająk, L. Sorn, Z kaszëbsczim w szkòle; J. Labùda, Zôrno mòwë: pòdrãcznik do ùczbë jãzëka kaszëbsczégò dlô pòczątkújącëch; J. Labùda, Zdrój słowa. Na poziomie gimnazjum: D. Pioch, Òjczëstô mòwa. Na poziomie szkoły ponadgimnazjalnej: F. Baska-Borzyszkowska, W. Myszk, Kaszëbë. Jô w kaszëbsczi, kaszëbskô w swiece, cz. 1 i cz. 2.
} 


\section{Wykorzystanie mediów elektronicznych}

Zważywszy na ograniczony krąg czytelników literatury kaszubskiej - co wiąże się z nie tak dawnym wprowadzeniem kaszubszczyzny do systemu oświaty, a więc także z dość powszechnym wciąż zjawiskiem pewnego rodzaju analfabetyzmu wśród dorosłych użytkowników języka kaszubskiego - ważne dla literatury kaszubskiej są współczesne kanały jej upowszechniania: media elektroniczne, audiobooki czy e-książki.

Jako jedni z pierwszych zwrócili na to uwagę twórcy telewizyjnego magazynu kaszubskiego „Rodnô Zemia” (Prëczkòwsczi 2003). Przez dwa lata (20002002) w tym magazynie, emitowanym przez gdański oddział TVP, w ramach lekcji kaszubskiego z udziałem dzieci powstało trzydzieści tekstów piosenek, które wraz z zapisem nutowym w 2003 roku opublikowano w książce Piesnie Rodny Zemi (Fópka, Prëczkòwsczi, Stachùrsczi 2003).

Na szczególną uwagę zasługuje trwający już od 2011 roku projekt Kaszubskie Bajania. Jest to kampania społeczna realizowana wspólnie przez Zrzeszenie Kaszubsko-Pomorskie oraz Radio Gdańsk. Jak piszą na stronie internetowej Akademii Bajki Kaszubskiej jej pomysłodawcy, „Powstała ona z myślą o dzieciach, aby już od najmłodszych lat zapoznawały się z dziedzictwem kulturowym Kaszub". Innym celem tej kampanii jest podniesienie świadomości w społeczeństwie o roli czytania dzieciom (Akademia Bajki Kaszubskiej 2011). Wydano już cztery płyty pod wspólnym tytułem Najpiękniejsze bajki i baśnie kaszubskie, na których głosu użyczyły znane postaci: kaszubscy artyści, twórcy, naukowcy, dziennikarze, samorządowcy i księża, a wśród nich Danuta Stenka, Maciej Miecznikowski, Rudi Schuberth, Krzysztof Skiba, profesor Jerzy Treder, profesor Józef Borzyszkowski, ks. Marian Miotk czy biegaczka Angelika Cichocka.

W ramach Kaszubskich Bajań odbywają się spotkania z dziećmi w przedszkolach, domach dziecka i szpitalach. Lektorzy czytają na nich dzieciom bajki, a także opowiadają o zwyczajach i obrzędach kaszubskich. Ważnym wydarzeniem tej kampanii społecznej jest Bajkowy Festyn Rodzinny z grami, zabawami, konkursami i występami zespołów dziecięcych (Akademia Bajki Kaszubskiej 2011), W tym miejscu warto jeszcze wspomnieć o wydawnictwie książkowo-płytowym przygotowanym przez Nadbałtyckie Centrum Kultury w Gdańsku. Do zbioru Òpòwiédz mie bôjkã. Opowiedz mi bajkę wyboru tekstów dokonał Dušan-Vladislav Paždjerski, slawista z Uniwersytetu Gdańskiego (Paždjerski 2010).

Kaszubski bohater literacki stał się także postacią gry komputerowej Stark Remus. W 2012 roku stworzyła ją fundacja „Aby Chciało się Chcieć” współfinansowana przez powiat kartuski. W trakcie rozgrywki gracz pomaga dziadkowi Remusowi w wiosennych porządkach, przy okazji ucząc się podstawowych kaszubskich rzeczowników. Gra ma już drugą, znacznie rozszerzoną wersję i cieszy się niesłabnącym zainteresowaniem wśród dzieci, nauczycieli i rodziców (Akademia Bajki Kaszubskiej 2011).

Prywatną inicjatywą stworzonej przez Tomasza Fopkę Kaszubskiej Agencji Artystycznej było z kolei wydanie dwóch audiobooków z klasyką literatury kaszubskiej. W 2013 roku w formie płyty dźwiękowej dotarł do słuchaczy poemat Hieronima Jarosza Derdowskiego Ó panu Czorlińsczim, co do Pùcka pò sécë jachôł. Dwa lata wcześniej ukazała się czytana przez Fopkego powieść Żëcé i przigodë Remusa Aleksandra Majkowskiego. 
Pamiętać jednak trzeba, że to nie Fopke pierwszy zmierzył się z powieścią Majkowskiego. Na początku lat dziewięćdziesiątych ubiegłego wieku pionierskiego czytania całości dokonał aktor Zbigniew Jankowski na potrzeby „Radiowego Magazynu Kaszubskiego" Na bôtach ëw bòrach pod redakcją Dominika Sowy i Leszka Szmidtkego. Nagranie to wydano na kasetach magnetofonowych i dlatego dziś powszechnie jest już w zasadzie nie do odtworzenia w warunkach domowych. Podobnie ma się rzecz z kasetą Gôdczi ëi wice wydaną w 1991 roku przez czasopismo „Tatczëzna”. Swoje literackie gawędy opowiadają na niej Józef Roszman i Roman Skwiercz. Także w latach dziewięćdziesiątych dwudziestego stulecia w Radiu Gdańsk dokonano radiowej adaptacji opowiadań Jana Drzeżdżona z tomu Zwònnik w interpretacji Artura Jabłońskiego oraz Misia Puchatka w kaszubskim tłumaczeniu i interpretacji Bożeny Szymańskiej-Ugowskiej. Nagrania te, po odtworzeniu na antenie radiowej, pozostają w archiwach Radia Gdańsk.

Powstałe w 2004 roku Radio Kaszëbë, którego nadawcą jest Stowarzyszenie Ziemia Pucka, emitowało w swoim programie oba audiobooki przygotowane przez Tomasza Fopke (Ò panu Czorlińsczim, co do Pùcka pò sécë jachôt i Żëcé i przigodë Remusa) oraz Figle gnieżdżewsczich gbùrów autorstwa Jana Patoka w interpretacji Fopkego. To nagranie jest dostępne na platformie plików dźwiękowych Soundcloud wykorzystywanej przez rozgłośnię (Patok 2014). Tam również można znaleźć słuchowisko radiowe na podstawie powieści Jablonsczégò Namerkôny, które Radio Kaszëbë emitowało w odcinkach w 2014 roku. W nagraniu wzięło udział dziesięciu lektorów, którzy nierzadko wcielali się w dwie, trzy role (Jablonsczi 2014). Dla Radia Kaszëbë fragmenty powieści Żôtti kam czytał jej autor Stanisław Janke. One także są dostępne na platformie Soundcloud (Janke 2014).

W trwającej 170 lat historii literatury kaszubskiej jej funkcja tożsamościowa pojawia się $\mathrm{w}$ niej z rozmysłem czy wręcz w zgodzie z przemyślanym projektem ideowym (Kalinowski 2014a). Pisarze próbują odpowiedzieć na podstawowe pytanie każdego przychodzącego na świat człowieka. Pytanie o „ja”, o swoją tożsamość zawsze stanowiło i stanowi niemałe wyzwanie. Literatura kaszubska tak w przeszłości, jak i teraz chce pomóc człowiekowi odnaleźć swoje miejsce w świecie. Nowoczesne techniki, w tym media elektroniczne, są doskonałymi narzędziami wsparcia w tym zadaniu stawianym przed literaturą. Są także pomocne w procesach edukacyjnych. Ich właściwe wykorzystanie może wzmocnić siłę przekazu literackiego tekstu, a co za tym idzie - także moc namysłu tożsamościowego Kaszubów.

\section{Literatura:}

Akademia Bajki Kaszubskiej, 2011, http://www.akademiabajkikaszubskiej.pl/ [dostęp: 29.04.2015].

Andersen H.Ch., 1996, Brzëgné kôczãa, dolm. J. Labùda, Głodnica-Gdiniô: Wydawnictwo Region.

Baska-Borzyszkowska F., 2013, Ùsôdzczi na wdôr..., Gdańsk: Zrzeszenie Kaszubsko-Pomorskie.

Ceynowa F.S., 2007, Rozmòwa Pòlôcha z Kaszëbq. Rozmòwa Kaszëbë z Pòlôchã, Gdańsk: Instytut Kaszubski.

Drzeżdżon J., 1986, Wspótczesna literatura kaszubska 1945-1980, Warszawa: Ludowa Spółdzielnia Wydawnicza. 
Drzeżdżon J., 1993, Twôrz Smãtka, Gdańsk: Wydawnictwo Arkona.

Drzeżdżon J., 2007, O etniczności [w:] Twarze Drzeżdżona, red. R. Mistarz, Gdańsk: Zrzeszenie Kaszubsko-Pomorskie.

Drzeżdżon R., 2009, Niesama, "Zymk” nr 8.

Drzeżdżon R., Fopke T., 2010, Rómka \& Tómka Kôrbiónka z felietónowi pòlëcë, Gdynia: Wydawnictwo Region.

Fópka T., Prëczkòwsczi E., Stachùrsczi J. (red.), 2003, Piesnie Rodny Zemi, Banino: Wydawnictwo Rost.

Grucza E., 2007, Literackie teksty kaszubskie i nauka kaszubszczyzny w szkołach podstawowych. Oczekiwania - programy - praktyka dydaktyczna [w:] Literatura kaszubska w nauce - edukacji-życiu publicznym, red. Z. Zielonka, Gdańsk: Instytut Kaszubski.

Jablonsczi A., 2013, Namerkôny, Gdynia: Wydawnictwo Region.

Jablonsczi A., 2014, Namerkôny, roman czëtają: P. Cyskòwsczi, A. Hébel, É. Jablonsczi, J. Jablonsczi, A. Jónkòwskô, N. Lãdowskô, M. Kropidłowskô, M.T. Meyer, K. Róda ë aùtór, http://radiokaszebe.pl/namerkony-dzel-1-roman-artura-jablonsczego/ [dostęp: 29.04.2015].

Janke S., 2014, Żôtti kam, http://radiokaszebe.pl/zolti-kam-stanislawa-janke-na-antenie-radia-kaszebe/ [dostęp: 29.04.2015].

Kalinowski D., 2014a, Mity fundacyjne w literaturze kaszubskiej [w:] Geografia wyobrażona regionu. Literackie figury przestrzeni, red. D. Kalinowski, M. Mikołajczak, A. Kuik-Kalinowska, Kraków: Towarzystwo Autorów i Wydawców Prac Naukowych Universitas.

Kalinowski D., 2014b, Nowy naród nad Battykiem. Kaszubskie powieści Artura Jabłońskiego, „Porównania” nr 15.

Kalinowski D., 2014c, Raptularz kaszubski, Gdańsk: Wydawnictwo Zrzeszenia Kaszubsko-Pomorskiego.

Kożyczkowska A., 2013, Kulturowe znakowanie człowieka: szkic na marginesie książki Namerkôny Artura Jabłońskiego, „,Rocznik Ruskiej Bursy”.

Kucharski R., Natrzecy J., 2009, Szczeniã Swiãców, Bytów: Kurier.

Kucharski R., Nowotnik M., 2015, Akademiô błotowëch żótwiów, Bytów: Zrzeszenie Kaszubsko-Pomorskie.

Kuik-Kalinowska A., Kalinowski D., 2009, Od Smętka do Stolema. Wokót literatury Kaszub, Gdańsk: Instytut Kaszubski Słupsk: Akademia Pomorska.

Kuik-Kalinowska A., 2011, Tatczëzna. Literackie przestrzenie Kaszub, Gdańsk: Instytut Kaszubski, Słupsk: Wydawnictwo Naukowe Akademii Pomorskiej.

Kuik-Kalinowska A., 2014, Stolemy. Kamienie w świecie literackiej wyobraźni Kaszub [w:] Geografia wyobrażona regionu. Literackie figury przestrzeni, red. D. Kalinowski, M. Mikołajczak, A. Kuik-Kalinowska, Kraków: Towarzystwo Autorów i Wydawców Prac Naukowych Universitas.

Linkner T., 1996, Heroiczna biografia Remusa. W zwierciadle mitu i kaszubskich wierzeń, Gdańsk: Oficyna Czec.

Lipski T., 1990, Remusowi króm. Wypisy z literatury kaszubskiej dla nauczycieli języka polskiego, Gdańsk: Zrzeszenie Kaszubsko-Pomorskie.

Majkowski A., 1938, Żëcé i przigodë Remusa, Toruń: Stanica.

Makurat H., 2010, Chléw, Gdynia: Wydawnictwo Region.

Makurat H., 2011, Testameńtë Jimaginacji, Kartuzy: Oficyna Czec.

Mëszk W., 2014, Kôrbiónka $z$ aniołã [w:] Lëdze sq lëdzama, Gdańsk: Zrzeszenie Kaszubsko-Pomorskie.

Meyer M.T., 2013, Zamkłô w słowach, Gdynia: Wydawnictwo Region.

Mistarz R., 2014, Dokonania i wyzwania edukacji kaszubskiej, „Edukacja Pomorska. Biuletyn Centrum Edukacji Nauczycieli" nr 64/65.

Natrzecy J., Rolbiecki K., 2012, Arbata, Bytów: Zrzeszenie Kaszubsko-Pomorskie. 
Patok J., 2014, Figle gnieżdżewsczich gbùrów, czyta T. Fopke, http://radiokaszebe.pl/figlegniezdzewsczich-gburow/ [dostęp: 29.04.2015].

Paždjerski D.V. (red.), 2010, Òpòwiédz mie bôjkã. Opowiedz mi bajkę, tłum. D, Pioch, Gdańsk: Nadbałtyckie Centrum Kultury.

Pioch D., 2001, Kaszëbë. Zemia i lëdze. Podręcznik do języka kaszubskiego z ćwiczeniami, Gdańsk: Zrzeszenie Kaszubsko-Pomorskie i Oficyna Czec.

Pòtrëkùs G., 2012, Zderzenia, Gdynia: Wydawnictwo Region.

Prëczkòwsczi E., 2003, Niech jidq midzë lëdzy [w:] Piesnie Rodny Zemi, wyb., òprôc. T. Fópka, E. Prëczkòwsczi, J. Stachùrsczi, Banino: Wydawnictwo Rost.

Pryczkowska E., Wejer T., Formela D., 2012, W krôjnie Grifa. Téatrowé scenarniczi, Gdańsk: Zrzeszenie Kaszubsko-Pomorskie.

Pryczkowski E. (red.), 1996, Dërchôj królewiónkò. Antologia dzysdniowi prozë kaszëbsczi, Gdynia: Wydawnictwo Szos.

Rompski J., 2009, Dramaty kaszubskie, oprac. A. Kuik-Kalinowska, D. Kalinowski, J. Treder, Wejherowo: Muzeum Piśmiennictwa i Muzyki Kaszubsko-Pomorskiej, Gdańsk: Instytut Kaszubski.

Schramke G., 2006, Snienia. Dniownik z emigracjë, „Zymk” nr 5.

Schramke G., 2014, Cegła na cegle [w:] Lëdze sq lëdzama, Gdańsk: Zrzeszenie Kaszubsko-Pomorskie.

Treder J. (red.), 2002, Język kaszubski: poradnik encyklopedyczny, Gdańsk: Wydawnictwo Uniwersytetu Gdańskiego.

Treder J., 2007, Wstęp [w:] F.S. Ceynowa, Rozmòwa Pòlôcha z Kaszëbą. Rozmòwa Kaszëbë $z$ Pòlôchã, Gdańsk: Instytut Kaszubski.

Wosiak-Śliwa R., Cybulski M., 1992, Kaszubski język literacki. Podręcznik dla lektoratów, Gdańsk: Oficyna Wydawnicza Graf.

Zgłoś dziecko na język kaszubski, 2015, http://kaszubi.pl/aktualnosci/aktualnosc/id/1051 [dostęp: 29.04.2015].

Żelazny W., 2006, Etniczność. Ład, konflikt, sprawiedliwość, Poznań: Wydawnictwo Poznańskie.

\section{Abstrakt}

Podstawową funkcją kaszubskojęzycznej literatury od samych jej początków - to jest już od ponad 170 lat - aż po dzień dzisiejszy wydaje się być zachowanie własnego "ja" Kaszubów, którzy dzięki więzi wywodzącej się z dziedzictwa kulturowego są odrębną wspólnotą etniczną. Czytelne dla literatury kaszubskiej motywy, figury czy obrazy, które wykształciły się w jej obrębie i są źródłem jej siły i kreacji, tworzą bogatą strukturę znaczeń oraz pretendują tę literaturę do pełnienia funkcji mitotwórczych. Współcześnie w literaturze kaszubskiej jak w lustrze odbijają się zmiany zachodzące w samoświadomości kulturowej najmłodszego pokolenia jej twórców i odbiorców. Literatura próbuje „oswajać" zjawiska globalne z impetem wdzierające się w kaszubską przestrzeń kulturową.

W edukacji szkolnej język kaszubski i literatura w nim tworzona zagościły na stałe z początkiem lat dziewięćdziesiątych XX wieku. Brakowało jednak nowych tekstów literackich kaszubskich autorów, a w szczególności prozy. Środowiska kaszubskie zareagowały na ten brak, organizując w 1995 roku Ogólnopolski Konkurs Prozatorski im. Jana Drzeżdżona. Dopiero w 2001 roku światło dzienne ujrzał pierwszy podręcznik z ćwiczeniami Kaszëbë. Zemia i lëdze. Podręcznik do języka kaszubskiego z ćwiczeniami, napisany przez nauczycielkę Danutę Pioch z myślą o dzieciach z klas I-III szkoły podstawowej. Zaraz potem zaczęło pojawiać się mnóstwo kolejnych podręczników i wypisów z literatury. Osobnym niemal już zjawiskiem staje się literatura kaszubska tworzona na potrzeby szkoły czy też raczej dla „odbiorcy szkolnego". 
Krąg czytelników literatury kaszubskiej jest ograniczony. Kaszubszczyznę wprowadzono do systemu oświaty stosunkowo niedawno, zatem szczególnego rodzaju analfabetyzm wśród dorosłych użytkowników języka kaszubskiego, nieczytanie i niepisanie w tym języku, jest powszechne. Dlatego ważne dla literatury kaszubskiej są nowoczesne metody jej upowszechniania: media elektroniczne, audiobooki czy e-książki. Kaszubski bohater literacki stał się także postacią z gry komputerowej Stark Remus. Nowoczesne techniki, w tym media elektroniczne, są również pomocne w procesach edukacyjnych. Ich właściwe wykorzystanie może wzmocnić siłę przekazu literackiego tekstu, a co za tym idzie - także moc namysłu tożsamościowego Kaszubów.

\section{Słowa kluczowe}

Kaszubi, literatura kaszubska, tożsamość, edukacja, media elektroniczne

\section{Summary}

\section{Kashubian Literature: Functions, Educational Potential and Using Electronic Media in Its Circulation}

For over 170 years now, that is from its early beginnings, the primary function of the literature written in the Kashubian language has been preserving the own voice of the Kashubs who thanks to ties derived from the cultural heritage, constitute a distinct ethnic community. The themes, figures or images characteristic of the Kashubian literature as a source of its strength and creative power form a rich structure of meanings responsible for the myth-making factor in that literary output. As in a mirror, the contemporary Kashubian literature reflects the changing cultural self-consciousness of the youngest generation of writers and readers. Literature is trying to "tame" the global phenomena, which force their way vehemently into the Kashubian cultural space.

Kashubian language and literature were included on a permanent basis in the educational system in the early 1990s. However there was a lack of new literary texts of Kashubian authors, and especially written in prose. The reaction of the Kashubian circles was organizing a Jan Drzeżdżon National Prose Competition in 1995. It was not earlier than in 2001 when the first textbook with exercises was published. Kaszëbë. Zemia and lëdze. Podręcznik do języka kaszubskiego z ćwiczeniami was written by the teacher Danuta Pioch for the children from classes I-III of the primary school. Since then there has been a real boom for the next school textbooks and extracts from literature - of course in the scale of Kashubian circles and their potential. A separate phenomenon can be observed, namely Kashubian literature created for the needs of school curriculas or rather for "the school audience".

Because of the limited number of Kashubian literature readers, which results from quite recent introduction of Kashubian to the educational system and fairly common illiteracy among adults, the most important for the Kashubian literature are modern channels of its distribution: electronic media, audio books and e-books. Kashubian protagonist has also become a character from a computer game Stark Remus. Modern technology, including electronic media, are also helpful in educational processes. Their proper use can enhance the effectiveness of the message of a literary text, and thus the power of identity consideration of the Kashubs.

\section{Keywords}

Kashubian, Kashubian literature, identity, education, electronic media 